\title{
Editorial: Corporate governance and class actions
}

Many of the players in corporate governance are now looking a little weary after a ten-year battle that has seen, in the UK at least, a slew of reports with a new consolidated code just now published, and in European and US jurisdictions a never-ending flurry of papers, reports and recommendations. One day company directors will actually concentrate on their day job of making widgets or selling services, but understandably after the corporate excesses of the nineties, investors are looking for them to pay heed to governance concerns. Corporate governance is just one of the many not always cheap - prices that directors have to pay if they wish to raise capital in the markets.

For pension funds, as investors, corporate governance is a benefit which should improve the security and return of their investments, although the cost/benefit analysis is not always easy to discern. In practice only the very largest pension funds operate their own corporate governance arrangements, most preferring to make use of the service providers, the most common in the UK being the National Association of Pensions Funds (NAPF), the Association of British Insurers (ABI), Pensions and Investment Research Consultants (PIRC) and Manifest (a voting advisory service). Whether that picture will remain as is for long seems unlikely — Manifest will most likely have to seek cover elsewhere when its funding runs out, and the NAPF has already entered into a joint venture with the US corporate governance operation Institutional Shareholder Services (ISS).

All these and others offer pension funds a service which considers the governance needs of their clients in different ways. Some include or even specialise in social and ethical issues arising out of governance.

But few spend much time or resource in one of the more intriguing areas of corporate governance activity, that of shareholder litigation, the ultimate weapon in the corporate governance armoury. Most shareholder litigation takes place in the USA, and most of it is not normally by a single pension fund acting against an errant corporation, but by a group of pension funds acting collectively and funded by a law firm. John Grisham's recent novel, King of Torts, explains how the system works rather graphically, but in the field of ethical drugs rather than securities. The standard method is for a specialist law firm to seek out a group of complainants with the same potential defendant and offer to act on behalf of all of them. This group is called a class. It is a sensible way of conducting litigation, because it spreads the costs - and the risks - of litigation, and makes it worthwhile for an individual fund to sue 
a large corporation. The way it works in the USA, and why it works less well in the UK, is that even if the pension fund trustees lose, they do not have to pay the defendant corporation's legal costs since in the USA each side pays its own legal costs. The other major difference in the USA is that the lawyers can afford to underwrite the legal costs of the complainants, which can run into millions, because they are allowed by the courts to take a higher risk fee if they succeed - around a third of the funds recovered. One of the major law firms in the business has apparently recovered around $\$ 30$ bn in the last ten years, with fees therefore of around $\$ 10 \mathrm{bn}$. US law firms therefore enjoy substantial fee income which is the envy of their colleagues in other areas of practice and arouses some jealousy among their subscribing clients. On the other hand they do speculate substantial resources in putting a case together and have no guarantee of success - although they select their cases carefully.

UK and European pension funds are now being asked by US law firms to consider the question of class actions in relation to the investments they hold, especially if they fail to perform and where there is evident abuse by directors of their position. At the moment this is limited to the investments they hold in the USA, but that geographical limitation may not persist for long. Recent corporate failures in the US (WorldCom, Enron) and elsewhere have highlighted several issues relating to corporate governance, and the question for trustees and their fund managers is whether there is an issue for UK pension funds in particular in attempting to claim for losses incurred as a consequence.

One particular question is what action, if any, non-US pension funds should take in the light of these developments, and especially whether it is appropriate to engage in securities class actions. A securities class action lawsuit is a lawsuit brought on behalf of a group of investors who have suffered an economic loss in a particular security as a result of fraudulent stock manipulation or other violations of securities laws. Such cases are brought by one or more investors in the stock, known as 'lead plaintiffs' on behalf of all others who have suffered financial losses as a result of purchasing shares in a company during the period of time the fraud or securities laws violations artificially inflated the value of the stock (known as the 'class period').

Class action lawyers are usually only paid if the case is successful, and then in an amount determined by the court to be fair and reasonable. Fair and reasonable means also having regard to the sums risked by the lawyers, the complexity of the case, the time spent and other factors, but the usual rule of thumb, as mentioned, is about a third of sums recovered.

In the USA the way such litigation is managed is controlled by the provisions of the Private Securities Litigation Reform Act 1995, introduced to limit abuse by US law firms. It provides that the most adequate lead plaintiff is the person (or persons) who, in the determination of the court, has the largest financial interest in the relief sought by the class. The 'largest financial interest' can be determined by the courts in a variety of different ways. Some courts operate on the basis of the value of the claim, others on the percentage of net worth lost. In some cases several persons can be appointed to serve jointly to act as lead plaintiffs. But US practice does not always translate easily to the UK, even though class actions nowadays are seen as part of the corporate governance armoury, and is touched on in the forthcoming ISS/NAPF Research Recommendations and Electronic Voting 
(RREV) Corporate Governance Service. Corporate governance of course has its limitations; the Securities and Exchange Commission issued a rule in April 2003 on disclosure of proxy voting policies by investment managers and pension funds which contains, as all US legislation must, a declaration on the Paperwork Reduction Act $1995 .{ }^{1}$ Not only is it very long indeed, but it requires, paradoxically, all responses in writing to be submitted in triplicate.

Non-US pension funds are slowly being sucked into the class action net. In recent years, as UK and European pension funds have diversified, they have acquired a small portfolio of US assets, some of which have inevitably included securities in respect of which class actions have started or been proposed. In principle, it would seem sensible to participate, since there is no risk as to costs, and it may be that there will be a benefit to the fund and, ultimately, the beneficiaries. Indeed, some observers suggest that trustees of pension funds, unless they have a very good reason not to, have a fiduciary obligation to participate.

On the other hand, for pension funds to be seen to be ambulance chasers, or to sacrifice a third of the potential damages in cases where they could run their own actions, may also be unacceptable. It is noticeable that not all US pension funds join all or even any such litigation; many of them are happy to be free riders on the existing claims.

Non-US pension funds have a number of options available to them in relation to securities class action. These options include:

— doing nothing;

— doing nothing but ensuring that claims are registered through their external asset managers;

- applying a blanket policy to joining all such actions;

— instructing US specialist law firms to maintain a watching brief;

— selecting suitable cases on a merit driven basis;

— instructing law firms on a fee rather than a contingency basis; in some cases this makes better financial sense;

- establishing a watch service to monitor US and European cases and suggest appropriate courses of action.

Pension funds may also need to consider policy in relation to non-US claims in the UK and Europe. But whatever they do they will increasingly need to develop a policy, especially since several of the US law firms are currently seeking to expand their empires outside the USA. For all the reasons explored above it is likely that many of their overtures will be received coolly, but it may be that with the expansion of the fiduciary principle to both UK and European pension funds through the provisions of the forthcoming EU Pensions Directive, pension fund trustees will need to have a very good reason indeed to avoid at least exploring the opportunities offered by participation in securities class actions.

Robin Ellison Editor

\section{Reference}

1 Securities and Exchange Commission (2003) 'Disclosure of proxy voting policies and proxy voting records by registered investment management companies', 17 CFR Parts 239, 249, 270 and 274 Release Nos 33-8188, 34-47304, IC-25922; File No S7-36-02, RIN 3235-AI64, 14th April, available at www.sec.gov/rules/final/33-8188.htm. 